\title{
IMPLEMENTASI KURIKULUM 2013 MATA PELAJARAN \\ PENDIDIKAN AGAMA ISLAM DI SD SWASTA \\ (Studi Kasus Pada Sekolah Dasar Swasta Islam Terpadu Permata Cendekia)
}

\author{
Indah Sari Irmadani \\ Mahasiswa S2 FITK UIN SU Medan
}

Abstrak

Sekolah Dasar Islam Terpadu (SDIT) Permata Cendekia Kecamatan Siantar Kabupaten Simalungun adalah sekolah yang unik. Karena sebelum kurikulum 2013 dijalankan di sekolah ini, konsep Sekolah Islam Terpadu sudah mengimplementasikan sikap spiritual dan sikap sosial dalam aktivitas pembelajaran. Dengan adanya kurikulum 2013 ini, maka lengkaplah dua konsep kurikulum 2013 menyatu dengan kurikulum Jaringan Islam terpadu. Fakta yang unik adalah kompetensi sikap spiritual dan sikap sosial dan juga kompetensi aspek pengetahuan dan keterampilan yang berasal dari Pemerintah Pusat, Sekolah Dasar Islam Terpadu juga memiliki kurikulum tambahan yang berasal dari Sekolah Islam terpadu.

\section{Kata Kunci: Kurikulum, PAI}

\section{PENDAHULUAN}

Kurikulum 2013 adalah kurikulum berbasis kompetensi, pengembangan kurikulum 2013 diarahkan pada pencapaian kompetensi yang dirumuskan dari Standar Kompetensi Lulusan (SKL). Penyusunan kurikulum 2013 dimulai dengan menetapkan standar kompetensi lulusan berdasarkan kesiapan peserta didik dan tujuan pendidikan nasional. Kurikulum 2013 ditetapkan menjadi alat peyelenggara pendidikan pertama kali pada tahun ajaran 2013/2014 pada sejumlah sekolah sasaran (Martiyono, dkk. 2014:38).

Berdasarkan Kurikulum 2013 peserta didik tidak lagi menjadi obyek dari pendidikan, tetapi menjadi subyek dalam mengembangkan tema dan materi yang ada. Proses penilaian dalam kurikulum 2013 menggunakan penilaian otentik yaitu mengukur semua kompetensi sikap, keterampilan, dan pengetahun berdasarkan proses dan hasil. Regulasi terbaru yang mengatur penilaian dalam kurikulum 2013 adalah Permendikbud nomor 23 tahun 2016.

Sekolah Dasar Islam Terpadu (SDIT) Permata Cendekia termasuk diantara sejumlah sekolah dasar yang ada di kabupaten Simalungun khususnya di Kecamatan Siantar, telah menerapkan kurikulum 2013 sejak 
tahun pelajaran 2016/2017. Sekolah dasar lainnya juga menerapkan kurikulum 2013 di sekolah masing-masing seperti di Sekolah Dasar 097523 Perumnas Batu VI Kecamatan Siantar, namun berdasarkan penelitian awal ditemukan bahwa banyak keunggulan yang signifikan yang dilakukan oleh Sekolah Dasar Islam Terpadu (SDIT) Permata Cendekia Siantar baik dibidang akademik maupun non akademik.

Program unggulan bidang Pendidikan Agama Islam yang menarik adalah program tahfizh yang menjadi program unggulan dari sekolah ini. Siswa/siswi sampai tamat kelas 6 harus hapal juz 30 dan ada beberapa yang dapat menyelesaikan sampai 3 atau 4 juz hapalan ketika tamat kelas 6 di Sekolah Dasar Islam Terpadu (SDIT) Permata Cendekia. Bidang akademik diantaranya salah satu siswi kelas 5 SDIT menjadi utusan lomba Pentas PAI tingkat Propinsi Sumatera Utara untuk bidang Pidato Puteri. Berikutnya menjadi utusan untuk musabaqah tilawatil qur'an tingkat kabupaten Simalungun untuk bidang tilawah anak-anak. Bidang akademik lainya yang ditunjukkan di Sekolah Dasar Islam Terpadu Permata Cendekia adalah program kunjungan ke rumah siswa yang sedang mengalami sakit atau kematian dengan memberangkatkan satu kelas bersama wali kelas, ini termasuk pengamalan nilai-nilai saling menolong dari bab pembelajaran yang diterima siswa di dalam kelas.

Uraian di atas mengindikasikan bahwa kurikulum 2013 telah berjalan di Sekolah Dasar Islam Terpadu (SDIT) Permata Cendekia yaitu tiga ranah yang hendak ditumbuh kembangkan pada diri siswa/siswi yaitu sikap, pengetahuan dan keterampilan yang dilaksanakan secara berimbang. Sikap dikembangkan menjadi dua yaitu sikap spiritual dan sikap sosial.

Fakta yang unik adalah kompetensi sikap spiritual dan sikap sosial dan juga kompetensi aspek pengetahuan dan keterampilan yang berasal dari Pemerintah Pusat, Sekolah Dasar Islam Terpadu juga memiliki kurikulum tambahan yang berasal dari Sekolah Islam terpadu.

\section{KAJIAN TEORETIS}

\section{Sekolah Islam Terpadu (SIT)}

Sekolah Islam Terpadu (SIT) pada hakekatnya adalah sekolah yang mengimplementasikan konsep pendidikan Islam berlandaskan Al Qur'an dan As Sunnah (JSIT (2014:5). SIT diartikan sebagai sekolah yang menerapkan pendekatan penyelenggaraan dengan memadukan pendidikan umum dan pendidikan agama menjadi satu jalinan kurikulum. Dengan pendekatan ini, semua mata pelajaran dan semua 
kegiatan sekolah tidak lepas dari bingkai ajaran dan pesan nilai Islam. Tidak ada dikotomi, tidak ada keterpisahan, tidak ada "sekularisasi" dimana pelajaran dan semua bahasan lepas dari nilai dan ajaran Islam, ataupun "sakralisasi" dimana Islam diajarkan terlepas dari konteks kemaslahatan kehidupan masa kini dan masa deepan. Pelajaran umum, seperti matematika, IPA,IPS, bahasa, jasmani/kesehatan, keterampilan dibingkai dengan pijakan, pedoman dan panduan Islam. Sementara pelajaran agama, kurikulum diperkaya dengan pendekatan konteks kekinian dan kemanfaatan, dan kemaslahatan.

Konsep operasional SIT merupakan akumulasi dari proses pembudayaan, pewarisan dan pengembangan ajaran agama Islam, budaya dan peradaban Islam dari generasi ke generasi. Istilah "Terpadu" dalam SIT dimaksudkan sebagai penguat (taukid) dari Islam itu sendiri. Maksudnya adalah Islam yang utuh menyeluruh, integral, bukan parsial, syumuliah bukan juz'iyah. Hal ini menjadi semangat utama dalam gerak da'wah dalam bidang pendidikan ini sebagai "perlawanan" terhadap pemahaman sekuler, dikotomi, juz'iyah. (https://jsitindonesia.com/sample-page/pengertian-sekolah-islam-terpadu/ di unduh pada tanggal: 31/10/2017, pukul 11.06.).

SIT juga memadukan pendidikan aqliyah, ruhiyah, dan jasadiyah. Artinya, SIT berupaya mendidik peserta didik menjadi anak yang berkembang kemampuan akal dan intelektualnya, meningkat kualitas keimanan dan ketaqwaannya kepada Allah SWT, terbina akhlak mulia, dan juga memiliki kesehatan, kebugaran dan keterampilan dalam kehidupannya sehari-hari. (https://jsit-indonesia.com/samplepage/pengertian-sekolah-islam-terpadu/ diunduh pada tanggal 31/10/2017, pukul 11.06.).

SIT memadukan keterlibatan dan partisipasi aktif lingkungan belajar yaitu: sekolah, rumah dan masyarakat. SIT berupaya untuk mengoptimalkan dan sinkronisasi peran guru, orang tua dan masyarakat dalam proses pengelolaan sekolah dan pembelajaran sehingga terjadi sinergi yang konstruktif dalam membangun kompetensi dan karakter peserta didik .orang tua dilibatkan secara aktif untuk memperkaya dan memberi perhatian yang memadai dalam proses pendidikan putra-putri mereka. Sementara itu, kegiatan kunjungan ataupun interaksi keluar sekolah merupakan upaya untuk mendekatkan peserta didik terhadap dunia nyata yang ada di masyarakat.

Sekolah Islam Terpadu juga memadukan pendidikan aqliyah, ruhiyah dan jasadiyah. Artinya SIT berupaya mendidik peserta didik 
menjadi anak yang berkembang kemampuan akal dan intelektualnya, meningkat kualitas keimanan dan ketaqwaannya kepada Allah SWT, terbina akhlak mulia, dan juga memiliki kesehatan, kebugaran, dan keterampilan dalam kehidupannya sehari-hari. Sekolah Islam Terpadu memadukan keterlibatan dan partisipasi aktif lingkungan belajar yaitu: sekolah, rumah dan masyarakat. SIT berupaya untuk mengoptimalkan dan sinkronisasi peran guru, orang tua dan masyarakat dalam proses pengelolaan sekolah dan pembelajaran sehingga terjadi sinergi yang konstruktif dalam membangun kompetensi dan karakter peserta didik. Orang tua dilibatkan secara aktif untuk memperkaya dan memberi perhatian yang memadai dalam proses pendidikan putra-putri mereka. Sementara itu, kegiatan kunjungan ataupun interaksi ke luar sekolah merupakan upaya untuk mendekatkan peserta didik terhadap dunia nyata yang ada di tengah masyarakat. JSIT (2014:5).

\section{Metode Pendidikan Sekolah Islam Terpadu}

Model pembelajaran di Sekolah Islam Terpadu yakni: Dialog, diskusi dan curah pendapat, belajar sambil berbuat, visitasi, metode belajar sinektik atau kreatif, dan belajar berbantuan komputer yang berkendali dan terarah.

Segala bentuk metode pembelajaran di atas tidak akan maksimal jika tidak didukung oleh alat pendidik, karena bagaimanapun alat pendidikan memiliki andil besar dalam konsep sekolah Islam Terpadu, beberapa alat pendidikan yang harus ada di dalam sekolah Islam Terpadu yaitu: pembiasaan, keteladanan, kasih sayang, kesabaran, kemitraan, respek, kepedulian dan encouraging

Dalam Sekolah Islam Terpadu, muatan kurikulum sama dengan sekolah pada umumnya. Mata pelajaran yang disampaikan terdiri dari mata pelajaran yang ditetapkan oleh pemerintah pusat. Namun dalam Sekolah Islam Terpadu terdapat kegiatan pengembangan diri yang wajid diikuti oleh seluruh siswa. Bidang pengembangan antara lain seperti: life skill, pramuka. tahsin tahfidz, dan. pendampingan

\section{Prinsip Sekolah Islam Terpadu}

Sekolah Islam Terpadu adalah sekolah yang bertekad keras untuk menjadikan nilai dan ajaran Islam terjabarkan dalam seluruh aspek yang terkait dengan penyelenggaraan sekolah. Menurut JSIT, (2014:7) prinsipprinsip penyelenggaraan Sekolah Islam Terpadu berintikan: (1) meyakini bahwa pendidikan Islam merupakan aktivitas dakwah yang merupakan 
pekerjaan mulia dan menuntut dedikasi, loyalitas, dan kerja keras, (2) pendidikan diselenggarakan dengan tulus ikhlas, dedikasi yang tinggi dan cara-cara yang bijak dan dipandang sebagai kewajiban menjalankan perintah Allah SWT: mengajak, menuntun manusia menuju jalan Allah (QS 16:125). Menjalankan aktivitas pendidikan merupakan amanah yang diterima dari orang tua siswa, dan menunaikan amanah merupakan perintah Allah SWT, yang harus ditunaikan dengan baik, professional dan penuh tanggung jawab ( An-Nisa':58), dan (3) pendidikan pada hakekatnya adalah mengajarkan seluruh kandungan Islam (al Qur'an dan al Hadis) sebagai satu kesatuan "ilmu Allah". Oleh karenanya seluruh kandungan kurikulum di SIT dikembangkan berdasarkan keyakinan dan pandangan yang terpadu dan bersendikan ke-tauhid-an Allah SWT. Sekolah Islam Terpadu berupaya untuk mengintegrasikan ilmu Allah yang tersurat dalam al Qur'an dan al Hadis ('ulumul Qauliyah) dengan nilai kauniyah dan qauliyah dalam bangunan kurikulum. Pesan dan ajaran Islam yang terkandung dalam referensi al Qur'an, Hadis Nabi ataupun kitab-kitab klasik yang masyhur diintegrasikan ke dalam isi kurikulum pelajaran umum/non agama. Mengedepankan keteladanan yang baik (qudwah hasanah) dalam membentuk karakter peserta didik melalui perilaku seluruh tenaga pendidik dan tenaga kependidikan, utamanya aspek 'ubudiyah dan akhlaqiyah.

\section{Konsep Kurikulum 2013}

Kurikulum 2013 merupakan implementasi dari UU No 32 tahun 2013. Kurikulum 2013 ini merupakan kelanjutan dan penyempurna dari kurikulum berbasis kompetensi (KBK) dan KTSP. Akan tetapi lebih mengacu pada kompetensi sikap, pengetahuan dan keterampilan secara terpadu, sebagaimana amanat UU No. 20 Tahun 2003 tentang Sistem Pendidikan Nasional yang terdapat pada pasal 35, dimana kompetensi lulusan merupakan kualifikasi kemampuan lulusan yang mencakup sikap, pengetahuan dan keterampilan sesuai dengan standar nasional yang telah disepakati.

Pelaksanaan perubahan kurikulum 2006 menjadi Kurikulum 2013, berdasarkan PP Nomor 32 Tahun 2013. Fokus utama perubahan kurikulum 2013 meliputi empat standar Nasional Pendidikan, yaitu: (1) Standar Kompetensi Lulusan, (2) Standar Isi, (3) Standar Proses, dan (4) Standar Penilaian (Martiyono, dkk 2014:7).

Kurikulum 2013 merupakan pengembangan dari kurikulum sebelumnya untuk merespon berbagai tantangan internal dan eksternal. 
Titik tekan pengembangan kurikulum 2013 adalah penyempurnaan pola piker, penguatan tata kelola kurikulum, pendalaman dan perluasan materi, penguatan proses pembelajaran, dan penyesuaian beban belajar agar dapat menjamin kesesuaian antara apa yang diinginkan dengan apa yang dihasilkan. Pengembangan kurikulum menjadi amat penting sejalan dengan kontinuitas kemajuan ilmu pengetahuan, teknologi dan seni budaya serta perubahan masyarakat pada tataran lokal, nasional, regional, dan global di masa depan. Aneka kemajuan dan perubahan itu melahirkan tantangan internal dan eksternal di bidang pendidikan. Kerena itu, implementasi kurikulum 2013 merupakan langkah strategis dalam menghadapi globalisasi dan tuntutan masyarakat Indonesia masa depan (Direktorat PAI (2014:2)

\section{METODOLOGI PENELITIAN}

Penelitian ini dilaksanakan di Sekolah Dasar Islam Terpadu (SDIT) Permata Cendikia yang berada di Jalan Asahan Gg. MUI No. 2 Kelurahan Siantar Estate Kecamatan Siantar Kabupaten Simalungun Propinsi Sumatera Utara.Waktu penelitian dilakukan pada semester ganjil tahun pelajaran 2017/2018 tanggal 28 Agutus 2017 sampai 08 Maret 2018. Penelitian ini menggunakan model studi kasus (case study) dengan prosedur yang ditempuh dalam penelitian ini adalah sebagai berikut: (1) melakukan pengumpulan data, (2) melakukan interpretasi terhadap data sehingga ditemukan data otentik, dan menyimpulkan temuan yang telah dilakukan.

Sumber data adalah: (1) Kepala Sekolah, (2) Wakil Kepala Bidang Kurikulum, (3) Wakil Kepala Bidang Kesiswaan, dan (4) Guru PAI. Instrumen pengumpulan data adalah: (1) Wawancara Mendalam, dan (2) Observasi Partisipan. Analisis data yang dilakukan dalam penelitian ini berpedoman pada teknik analisis data model Huberman dan Miles yang terdiri dari; reduksi data, penyajian data, dan penarikan kesimpulan. Sugiyono, (1990:337) Selanjutnya untuk memperkuat pemeriksaan kesahihan data hasil temuan, maka peneliti mengacu kepada penggunaan standar keabsahan data yang terdiri dari: credibility, transperability, dependability dan comfirmability.

\section{HASIL PENELITIAN}

\section{Proses Implementasi Kurikulum 2013 Mata Pelajaran PAI.}

Berdasarkan hasil wawancara dengan bapak Solihin, S.Pd.I tentang rencana pelaksanaan pembelajaran diperoleh jawaban: Rencana 
Pelaksanaan Pembelajaran yang kami susun adalah RPP model 2013 yang didalamnya terdapat kegiatan pendahuluan, kegiatan inti dan kegiatan penutup. Didalam kegiatan inti terdapat pendekatan saintifik dengan $5 \mathrm{M}$, yaitu Mengamati, Menanya, Mengeksplorasi, Mengasosiasi dan Mengkomunikasi, namun dalam kompetensi dasar dan indikator tidak dicantumkan indikator pencapaian kompetensi untuk K.1 2 dan K1.2. Selanjutnya rublik penilaian semua disertakan (Wawancara dengan Bapak Solihin, S.Pd.I tanggal: 05 Maret tahun 2018).

Dilanjutkan dengan wawancara dengan Ibu Nurlina Manurung, S. Pd.I sebagai berikut ini: Kami susun Rencana Pelaksanaan Pembelajaran adalah RPP model 2013 yang didalamnya terdapat kegiatan pendahuluan, kegiatan inti dan kegiatan penutup. Didalam kegiatan inti terdapat pendekatan saintifik dengan $5 \mathrm{M}$, yaitu Mengamati, Menanya, Mengeksplorasi, Mengasosiasi dan Mengkomunikasi, namun dalam kompetensi dasar dan indikator tidak dicantumkan indikator pencapaian kompetensi untuk K.1 2 dan K1.2. Selanjutnya rublik penilaian semua disertakan, model ini saya dapatkan pada waktu saya mengikuti PLPG pada tahun 2015. (Wawancara dengan Ibu Nurlina Manurung, S.Pd.I tanggal: 08 Maret tahun 2018).

Berdasarkan hasil studi dokumen yang dilakukan peneliti terhadap RPP bapak Solihin, S.Pd.I Kelas 1 Semester Genap dengan tema Doa Belajar serta Semangat Belajar Nabi Idris AS. Dilanjutkan dengan studi dokumen RPP yang dimiliki Ibu Nurlina Manurung, S.Pd.I pada Kelas IV dengan tema Q.S Al Falaq dan Kisah Keteladanan Nabi Musa A.S didapatkan indikator pencapaian kompetensi K.1.1 dan K1.2 tidak disertakan, nampaknya mereka mengacu pedoman pembuatan rencana pelaksanaan pembelajaran berdasarkan permendikbud no. 81 A tahun 2013.

Penelitian dilanjutkan dengan materi dari setiap rencana pembelajaran yang dimiliki oleh guru PAI di SDIT Permata Cendekia. Berdasarkan hasil wawancara dengan bapak Solihin, S.Pd.I tentang judul rencana pelaksanaan pembelajaran diperoleh jawaban: Rencana Pelaksanaan Pembelajaran yang kami susun materinya kami susun berdasarkan tema. Kompetensi inti dari Pendidikan Agama Islam antara lain: kompetensi inti pertama yang terkait dengan sikap spiritual, kompetensi inti kedua terkait dengan sikap sosial, kompetensi inti ketiga yang terkait dengan pengetahuan dan kompetensi inti yang keempat yang terkait dengan keterampilan dikaitkan menjadi satu. Selanjutnya kompetensi inti ketiga yaitu pengetahuan menjadi tema utama. 
Alhamdulillah dalam buku guru dan buku siswa guru telah dibantu dengan tema-tema yang sudah ada seperti Doa Belajar serta Semangat Belajar Nabi Idris AS untuk kelas 1 (Wawancara dengan Bapak Solihin, S.Pd.I tanggal: 05 Maret tahun 2018).

\section{Hambatan-Hambatan Proses Implementasi Kurikulum 2013}

Secara umum hambatan-hambatan yang di hadapi SDIT Permata Cendekia sebagai berikut; (1) keadaan dan kemampuan tenaga pengajar sesungguhnya menjadi hal yang perlu diperhatikan, sebab tenaga pengajar sebagai sumber belajar, memegang peran yang sangat penting yang berkaitan erat dengan penguasaan materi pelajaran, begitu juga peran tenaga pengajar sebagai fasilitator, sebagai pengelola, sebagai demonstran, sebagai pembimbing, sebagai motivator, sebagai evaluator adalah suatu hal yang perlu dimiliki oleh setiap tenaga pengajar, (2) pada SDIT Permata Cendekia masih terdapat kekurangan sarana dan prasarana terutama dalam bidang kegiatan media pembelajaran. Hal ini dikemukakan oleh salah seorang guru PAI: Dalam proses belajar mengajar para guru PAI masih mendapat kesulitan bila berhadapan dengan materi yang membutuhkan media. Selain itu masih terdapat kekurangan buku paket kurikulum 2013 mata pelajaran Pendidikan Agama Islam bagi siswa, sehingga kadangkala guru harus menggunakan metode imla (dikte) yang banyak menhabiskan waktu. Hal ini sangat mempengaruhi keefektipan belajar dan ketercapai tujuan pembelajaran, (3) kurangnya pemahaman pihak sekolah (kepala sekolah dan guru), dan Kementerian Agama sebagai pihak yang diberikan amanah untuk memberikan bimbingan teknis tentang kurikulum 2013 pada mata pelajaran pendidikan Agama Islam, (4) kurangnya pemahaman para stakeholder terhadap pentingnya implementasi kurikulum 2013 berimplikasi negatif terhadap kurangnya bantuan anggaran pembiayaan untuk menyelenggarakan implementasi kurikulum 2013 mata pelajaran PAI ini, dan (5) terbatasnya pelatihan bagi guru berkonsekuensikan kepada terbatasnya pemahaman terhadap pola-pola baru dalam pengembangan strategi proses belajar mengajar dan RPP.

\section{Solusi Mengatasi Hambatan Proses Implementasi Kurikulum 2013.}

Beberapa solusi disampaikan oleh kepala sekolah berikut ini: (1) untuk permasalahan seperti guru kurang kreatif guru bisa di beritahu mengenai cara mengelola atau membuat proses pembelajaran menjadi menarik, mengenai cara pengkondisian kelas dengan baik, di berikan 
berbagai buku mengenai cara mendesain atau membuat kelas dengan baik dan masih banyak yang lainnya, (2) untuk guru yang mempunyai suara pelan diberi saran agar melatih suaranya dengan cara mengajar di depan kaca atau simulasi mengajar sendiri dengan demikian maka suara guru akan terlatih dan nantinya mampu terdengar lebih keras karena terbiasa, (3) diadakan suatu pelatihan - pelatihan mengenai kurikulum 2013 supaya nantinya guru dalam melaksanakan pembelajaran berbasis kurikulum 2013 bisa berjala dengan lancar, (4) diadakan workshop dan seminar mengenai kurikulum 2013, supaya nantinya guru bisa lebih mengetahui mengenai bagaimana kurikulum 2013, (5) adanya kegiatan sharing antar sekolah-sekolah, yang dimana bisa berguna menjadi tempat berbagi ilmu antara guru satu dengan yang lainnya mengenai apa itu kurikulum 2013, sehingga apabila ada suatu permasalahan nantinya bisa dibicarakan dengan seksama dan bisa diselesaikan dengan pemikiran bersama, (6) adanya supervisi yang dilakukan kepala sekolah untuk guru,dan (7) latihan terus menerus secara mandiri supaya nantinya mampu menerapkan pembelajaran dengan lebih baik.

\section{PEMBAHASAN}

Dalam Implementasi Kurikulum 2013 ini, sekolah bekerja dalam koridor-koridor tertentu antara lain sebagai berikut: (1) sumber daya; sekolah harus mempunyai fleksibilitas dalam mengatur semua sumber daya sesuai dengan kebutuhan setempat. Selain pembiayaan operasional/administrasi, pengelolaan keuangan harus ditujukan untuk: Memperkuat sekolah dalam menentukan dan mengalokasikan dana sesuai dengan skala prioritas yang telah ditetapkan untuk proses peningkatan mutu, pemisahan antara biaya yang bersifat akademis dari proses pengadaannya, (2) pertanggungjawaban, sekolah dituntut untuk memiliki akuntabilitas baik kepada masyarakat maupun pemerintah. Hal ini merupakan perpaduan atas komitmen terhadap standar keberhasilan dan harapan /tuntutan orang tua/ masyarakat. Pertanggungjawaban bertujuan untuk meyakinkan bahwa dana masyarakat dipergunakan sesuai dengan kebijakan yang telah ditentukan dalam rangka meningkatkan kualitas pendidikan dan jika mungkin untuk menyajikan informasi mengenai apa yang telah dikerjakan. Untuk itu sekolah harus memberikan laporan pertanggungjawaban dan mengkomunikasikannya kepada orang tua/masyarakat dan pemerintah dan melaksanakan kaji ulang secara menyeluruh terhadap pelaksanaan program prioritas sekolah dalam proses peningkatan mutu, (3) kurikulum; berdasarkan kurikulum 
standar yang telah ditentukan secara nasional, sekolah bertanggung jawab untuk mengembangkan kurikulum baik dari standar materi (content) dan proses penyampaiannya, (4) personil sekolah; sekolah bertanggung jawab dan terlibat dalam proses rekrutmen (dalam arti penentuan jenis guru yang diperlukan) dan pembinaan struktural staf sekolah (kepala sekolah, wakil kepala sekolah, guru dan staf lainnya). Sementera itu pembinaan profesional dalam rangka pembangunan kapasitas/kemampuan kepala sekolah dan pembinaan keterampilan guru dalam pengimplementasian kurikulum termasuk staf kependidikan lainnya dilakukan secara terus menerus atas inisiatif sekolah, (5) konsekuensi logis dari itu, sekolah harus diperkenankan untuk mengembangkan perencanaan pendidikan dan prioritasnya di dalam kerangka acuan yang dibuat oleh pemerintah. Memonitor dan mengevaluasi setiap kemajuan yang telah dicapai dan menentukan apakah tujuannya telah sesuai dengan kebutuhan untuk peningkatan mutu. Menyajikan laporan terhadap hasil dan performanya kepada masyarakat dan pemerintah sebagai konsumen dari layanan pendidikan (pertanggung jawaban kepada stake-holders)

Tanggung jawab peningkatan kualitas pendidikan secara mikro telah bergeser dari birokrasi ke pusat unit pengelola yang lebih dasar yaitu sekolah. Kondisi ini telah membawa kepada suatu kesadaran bahwa hanya sekolah yang dikelola secara efektiflah (dengan manajemen yang berbasis sekolah) yang akan mampu merespon aspirasi masyarakat secara tepat dan cepat dalam hal mutu pendidikan. Institusi pusat memiliki peran yang penting, tetapi harus mulai dibatasi dalam hal yang berhubungan dengan membangun suatu visi dari sistem pendidikan secara keseluruhan, harapan dan standar bagi siswa untuk belajar dan menyediakan dukungan komponen pendidikan yang relatif baku atau standar minimal. Konsep ini menempatkan pemerintah dan otoritas pendidikan lainnya memiliki tanggung jawab untuk menentukan kunci dasar tujuan dan kebijakan pendidikan dan memberdayakan secara bersama-sama sekolah dan masyarakat untuk bekerja di dalam kerangka acuan tujuan dan kebijakan pendidikan yang telah dirumuskan secara nasional dalam rangka menyajikan sebuah proses pengelolaan pendidikan yang secara spesifik sesuai untuk setiap komunitas masyarakat.

Pendanaan, walaupun dianggap penting dalam perspektif proses perencanaan di mana tujuan ditentukan, kebutuhan diidentifikasikan, kebijakan diformulasikan dan prioritas ditentukan, serta sumber daya dialokasikan, tetapi fokus perubahan kepada sistem manajemen berbasis sekolah ini lebih kepada bentuk pengelolaan yang mengekspresikan diri 
secara benar kepada tujuan akhir yaitu mutu pendidikan di mana berbagai kebutuhan siswa untuk belajar terpenuhi. Untuk itu dengan memperhatikan kondisi geografik dan sosio ekonomik masyarakat, maka sumber daya dialokasikan dan didistribusikan kepada sekolah dan pemanfaatannnya dipercayakan kepada sekolah sesusai dengan perencanaan dan prioritas yang telah ditentukan oleh sekolah dan dengan dukungan masyarakat. Pedoman pelaksanaan peningkatan mutu kalaupun ada hanya bersifat umum yang memberikan rambu-rambu mengenai apa-apa yang boleh/tidak boleh dilakukan.

Mengembangkan model program pemberdayaan sekolah. Bukan hanya sekedar melakukan pelatihan Kurikulum 2013, yang lebih banyak dipenuhi dengan pemberian informasi kepada sekolah. Model pemberdayaan sekolah berupa pendampingan atau fasilitasi dinilai lebih memberikan hasil yang lebih nyata dibandingkan dengan pola-pola lama berupa penataran Kurikulum 2013.

Pemberian Kewenangan. Kurikulum 2013 memberikan kewenangan kepada sekolah untuk mengkontrol sumber daya manusia, fleksibilitas dalam merespon kebutuhan masyarakat, misalnya pengangkatan tenaga honorer untuk keterampilan yang khas atau muatan lokal. Demikian pula mengirim guru untuk berlatih di institusi yang dianggap tepat.

Berdasarkan dari hasil penelitian pada guru SDIT Permata Cendekia mengenai proses pembelajaran berbasis kurikulum 2013 memiliki landasan hukum yaitu adalah Permendikbud Nomor 22 tahun 2016 tentang Standar Proses yang berisikan Standar Kompetensi Lulusan dan Standar Isi maka prinsip pembelajaran yang digunakan: a). Dari peserta didik diberi tahu menuju peserta didik mencari tahu; b). Dari guru sebagai satu-satunya sumber belajar menjadi belajar berbasis aneka sumber belajar; c). Dari pendekatan tekstual menuju proses sebagai penguatan; d). Penggunaan pendekatan ilmiah dari pembelajaran berbasis konten menuju pembelajaran berbasis kompetensi; e). Dari pembelajaran parsial menuju pembelajaran terpadu; f). Dari pembelajaran yang menekankan jawaban tunggal menuju pembelajaran dengan jawaban yang kebenarannya multi dimensi; g.) Dari pembelajaran verbalisme menuju keterampilan aplikatif; h.) Peningkatan dan keseimbangan antara keterampilan fisikal (hardskills) dan keterampilan mental (softskills); i). Pembelajaran yang mengutamakan pembudayaan dan pemberdayaan peserta didik ebagai pembelajar sepanjang hayat; j). Pembelajaran yang menerapkan nilai-nilai dengan member keteladanan(ing ngarso sung 
tulodo), membangun kemauan (ing madyo mangun karso), dan mengembangkan kreativitas peserta didik dalam proses pembelajaran (tut wuri handayani); k). Pembelajaran yang berlangsung di rumah, di sekolah, dan di masyarakat; l). Pembelajaran yang menerapkan prinsip bahwa siapa saja adalah guru, siapa saja adalah siswa, dan di mana saja adalah kelas; m). Pemanfaatan teknologi informasi dan komunikasi untuk meningkatkan efisiensi dan efektivitas pembelajaran; dan n). Pengakuan atas perbedaan individual dan latar belakang budaya peserta didik.

Hal tersebut didukung oleh pendapat Suryosubroto (2009:134) yakni yang mengungkapkan ciri-ciri dan prinsip pembelajaran berkurikulum 2013 adalah: a). Berpusat pada siswa Proses pembelajaran yang dilakukan harus menempatkan siswa sebagai pusat aktivitas dan harus mampu memperkaya pengalaman belajar. Pengalaman belajar tersebut dituangkan dalam kegiatan belajar mengajar yang menggali dan mengembangkan fenomena alam di sekitar siswa; b). Memberikan pengalaman langsung kepada siswa Agar pembelajaran lebih bermakna maka siswa perlu belajar langsung dan mengalami sendiri proses pembelajaran yang sedang berlangsung. Atas dasar ini maka guru perlu menciptakan kondisi belajar yang kondusif dan memfasilitasi tumbuhnya pengalaman yang bermakna; c). Pemisahan mata pelajaran tidak begitu jelas Mengingat tema yang dikaji dari berbagai mata pelajaran dan saling keterkaitan maka batas mata pelajaran menjadi tidak begitu jelas; d).Menyajikan konsep berbagai mata pelajaran dalam suatu proses pembelajaran; e). Bersifat fleksibel Pelaksanaan pembelajaran tematik tidak terjadwal secara ketat antar mata pelajaran; f). Hasil pembelajaran data berkembang sesuai dengan minat, dan kebutuhan siswa.

Selanjutnya disebutkan bahwa Isi kurikulum 2013 dikembangan dalam bentuk kompetensi Inti dan kompetensi dasar. Kompetensi inti dikembangkan dari standar kompetensi lulusan dan merupakan kualitas minimal yang harus dikuasai peserta didik di kelas tertentu, isi umum materi pelajaran, dan ruang lingkup penerapan kompetensi yang dipelajari. Jenjang kompetensi dalam kompetensi inti meningkat untuk kelas-kelas berikutnya, kompetensi inti tidak memuat konten khusus mata pelajaran tetapi konten umum yaitu: fakta, konsep, prosedur, metakognitif dan kemampuan menerapkan pengetahuan yang terkandung dalam setiap mata pelajaran.

Perluasan penerapan kompetensi yang dipelajari dinyatakan dalam kompetensi inti, dimulai dari lingkungan terdekat sampai kelingkungan global. Dalam desain kurikulum 2013, kompetensi inti berfungsi sebagai 
pengikat bagi kompetensi dasar. Oleh karena itu, setiap komptensi dasar yang dikembangkan harus mengacu kepada kompetensi inti.

Pada setiap kegiatan pasti akan ada suatu masalah yang akan muncul, apakah masalah itu kecil ataupun besar, maka dari itu dibutuhkan suatu solusi untuk memecahkan masalah tersebut, jadi untuk menghindari dan menyelesaikan masalah yang mungkin akan terjari pada proses belajar mengajar dikelas bisa dilakukan dengan cara sebagai berikut: (1) untuk permasalahan seperti guru kurang kreatif guru bisa di beritahu mengenai cara mengelola atau membuat proses pembelajaran menjadi menarik, mengenai cara pengkondisian kelas dengan baik, di berikan berbagai buku mengenai cara mendesain atau membuat kelas dengan baik dan masih banyak yang lainnya, (2) untuk guru yang mempunyai suara pelan diberi saran agar melatih suaranya dengan cara mengajar di depan kaca atau simulasi mengajar sendiri dengan demikian maka suara guru akan terlatih dan nantinya mampu terdengar lebih keras karena terbiasa, (3) diadakan suatu pelatihan - pelatihan mengenai kurikulum 2013 supaya nantinya guru dalam melaksanakan pembelajaran berbasis kurikulum 2013 bisa berjala dengan lancar, (4) diadakan workshop dan seminar mengenai kurikulum 2013, supaya nantinya guru bisa lebih mengetahui mengenai bagaimana kurikulum 2013, (5) adanya kegiatan sharing antar sekolah-sekolah, yang dimana bisa berguna menjadi tempat berbagi ilmu antara guru satu dengan yang lainnya mengenai apa itu kurikulum 2013, sehingga apabila ada suatu permasalahan nantinya bisa dibicarakan dengan seksama dan bisa diselesaikan dengan pemikiran bersama, (6) belajar mengenai manajemen kelas dengan baik, karena pada pembelajaran kurikulum 2013 ini cara belajarnya sangat menarik, dengan demikian akan membuat suasana yang gaduh untuk itu guru harus mampu memanajemen kelasnya supaya suasana didalam kelas selalu dalam kondisi yang kondusif, (7) adanya supervisi yang dilakukan kepala sekolah untuk guru, dan (8) latihan terus menerus secara mandiri supaya nantinya mampu menerapkan pembelajaran dengan lebih baik

\section{SIMPULAN}

Berdasarkan hasil analisis dan pembahasan seluruh tahapan penelitian ini, penulis menarik kesimpulan bahwa implementasi kurikulum 2013 mata pelajaran pendidikan Agama Islam di sekolah SDIT Permata Cendekia adalah sebagai berikut ini: (1) proses Implementasi Kurikulum 2013 pada Mata Pelajaran PAI di SDIT Permata Cendekia 
dilaksanakan oleh dua orang guru Pendidikan Agama Islam dengan menggunakan model RPP yang berpedoman pada Permendikbud No. 81 A Tahun 2013, menggunakan model tematik, penyampaian materi pelajaran dengan pendekatan saintifik menggunakan teknik $5 \mathrm{M}$ sesuai karakteristik materi pelajaran serta menggunakan penilaian otentik melalui alat bantu aplikasi nilai dari komputer, (2) hambatan-Hambatan Proses Implementasi Kurikulum 2013 pada Mata Pelajaran PAI di SDIT Permata Cendekia adalah berkaitan dengan masalah internal dan eksternal guru PAI serta masalah media pendukung kegiatan pembelajaran, dan (3) solusi mengatasi Hambatan Proses Implementasi Kurikulum 2013 pada Mata Pelajaran PAI di SDIT Permata Cendekia adalah sebagai berikut ini: a) permasalahan seperti guru kurang kreatif guru bisa di beritahu mengenai cara mengelola atau membuat proses pembelajaran menjadi menarik, mengenai cara pengkondisian kelas dengan baik, di berikan berbagai buku mengenai cara mendesain atau membuat kelas dengan baik dan masih banyak yang lainnya; b). Untuk guru yang mempunyai suara pelan diberi saran agar melatih suaranya dengan cara mengajar di depan kaca atau simulasi mengajar sendiri dengan demikian maka suara guru akan terlatih dan nantinya mampu terdengar lebih keras karena terbiasa; c). Diadakan suatu pelatihanpelatihan mengenai kurikulum 2013 supaya nantinya guru dalam melaksanakan pembelajaran berbasis kurikulum 2013 bisa berjala dengan lancar; d). Diadakan workshop dan seminar mengenai kurikulum 2013, supaya nantinya guru bisa lebih mengetahui mengenai bagaimana kurikulum 2013; e). Adanya kegiatan sharing antar sekolah-sekolah, yang dimana bisa berguna menjadi tempat berbagi ilmu antara guru satu dengan yang lainnya mengenai apa itu kurikulum 2013, sehingga apabila ada suatu permasalahan nantinya bisa dibicarakan dengan seksama dan bisa diselesaikan dengan pemikiran bersama; f). Adanya supervisi yang dilakukan kepala sekolah untuk guru; g). Latihan terus menerus secara mandiri supaya nantinya mampu menerapkan pembelajaran dengan lebih baik; h). Solusi dari SDIT Permata Cendekia ini mengenai media pendukung proses pembelajaran atau yang sering disebut dengan alat peraga bahwa selain membeli alat peraga SD ini telah membuat sendiri alat peraga yang mereka butuhkan untuk mendukung peningkatan kualitas pembelajaran yang akan berlangsung. 


\section{REKOMENDASI}

Berdasarkan kesimpulan dari hasil penelitian di atas, penelitis mengajukan beberapa rekomendasi sebagai berikut ini: (1) diadakan suatu pelatihan - pelatihan mengenai kurikulum 2013 supaya nantinya guru dalam melaksanakan pembelajaran berbasis kurikulum 2013 bisa berjala dengan lancar, (2) diadakan workshop dan seminar mengenai kurikulum 2013, supaya nantinya guru bisa lebih mengetahui mengenai bagaimana kurikulum 2013, (3) adanya kegiatan sharing antar sekolah-sekolah, yang dimana bisa berguna menjadi tempat berbagi ilmu antara guru satu dengan yang lainnya mengenai apa itu kurikulum 2013, sehingga apabila ada suatu permasalahan nantinya bisa dibicarakan dengan seksama dan bisa diselesaikan dengan pemikiran bersama, (4) belajar mengenai manajemen kelas dengan baik, karena pada pembelajaran kurikulum 2013 ini cara belajarnya sangat menarik, dengan demikian akan membuat suasana yang gaduh untuk itu guru harus mampu memanajemen kelasnya supaya suasana didalam kelas selalu dalam kondisi yang kondusif, (5) adanya supervisi yang dilakukan kepala sekolah untuk guru, (6) diadakannya rapat bulanan, (7) diadakan rapat akhir semester untuk klarifikasi apa saja masalah yang terjadi pada semester tersebut.

\section{DAFTAR PUSTAKA}

Direktorat Pendidikan Agama Islam. (20140 Panduan Umum Implementasi Kurikulum 2013 Pendidikan Agama Islam dan Budi Pekerti, Kemenag RI.

Jaringan Sekolah Islam Terpadu, (20140 Standar Mutu :Kekhasan Sekolah Islam Terpadu, Jakarta.

Kementerian Pendidikan dan Kebudayaan. Kurikulum 2013: Kompetensi Dasar Sekolah Menengah Atas (SMA) dan Madrasah Aliyah (MA), 2013

Martiyono, dkk, (2014) Mengelola dan Mendampingi Implementasi Kurikulum 2013, Yogyakarta: Aswaja Pressindo.

Miles Matthew B. dan Huberman A. Michael, (1992) Analisis Data Kualitatif: Buku Sumber tentang Metode-Metode Baru, terj. Tjejep Rohendi Rohidi, Jakarta: UI Press.

Moleong, Lexy J. (2010) Metodologi Penelitian Kualitatif. Cet. Ke-27, Bandung:Remaja Rosdakarya. 
Mulyasa, (2013) Pengembangan dan Implementasi Kurikulum 2013, Bandung: Rosda Karya.

Sugiyono, (2013) Metode Penelitian Manajemen, Bandung: Alfabeta.

Undang - Undang Republik Indonesia No 20 Tahun 2003 Tentang Sistem Pendidikan Nasional. 